\title{
PENGARUH MODEL PEMBELAJARAN BERBASIS \\ MASALAH TERHADAP HASIL BELAJAR FISIKA \\ PADA SISWA KELAS XI SMA NEGERI 5 PALU
}

\author{
M. Ashad. $\mathrm{S}^{1^{*}}$ Muhammad Ali $^{1}$ dan Marungkil Pasaribu ${ }^{1}$ \\ Ashad_sukarman@yahoo.com \\ Program Studi Pendidikan Fisika, Jurusan MIPA, Universitas Tadulako \\ Jl. Soekarno Hatta KM.9 Palu, Indonesia
}

\begin{abstract}
Abstrak - Penelitian ini bertujuan untuk mengetahui ada tidaknya pengaruh model pembelajaran berbasis masalah terhadap hasil belajar fisika pada siswa kelas XI SMA Negeri 5 Palu. Penelitian ini menggunakan metode eksperimen kuasi dengan non equivalent control group design. Kelas XI IPA 1 sebagai kelas eksperimen, dan kelas XI IPA 3 sebagai kelas kontrol. Instrumen hasil belajar berupa tes berbentuk soal pilihan ganda yang telah diuji validitas dan reliabilitasnya. Analisis data menggunakan uji-t pada taraf signifikansi 0,05 dan dk= 52, dengan uji prasyarat normalitas dan homogenitas. Pengujian hipotesis menggunakan uji-t, dari hasil perhitungan statistik didapatkan harga thitung sebesar 3,98 dan tabel pada taraf signifikansi 0,05 dan dk = 52 adalah 2,01, hasil ini berada pada daerah penolakan Ho yakni $-t_{\text {tabel }}=2,01<t_{\text {hitung }}=3,98<t_{\text {tabel }}=2,01$. Penelitian ini menunjukkan bahwa hipotesis $(\mathrm{Ho})$ ditolak dan hipotesis penelitian $\left(\mathrm{H}_{1}\right)$ diterima atau terdapat perbedaan hasil belajar fisika antara kelas eksperimen dan kelas kontrol. Berdasarkan hasil uji hipotesis tersebut penelitian ini dapat disimpulkan bahwa terdapat pengaruh model pembelajaran berbasis masalah terhadap hasil belajar fisika pada siswa kelas XI SMA Negeri 5 Palu.
\end{abstract}

Kata Kunci: Pembelajaran Berbasis Masalah, Hasil Belajar

\section{PENDAHULUAN}

Proses pembelajaran pada setiap satuan pendidikan dasar dan menengah harus interaktif, inspiratif, menyenangkan, menantang dan memotivasi peserta didik. Proses pembelajaran berlangsung siswa ikut terlibat, agar siswa memperoleh pengalaman dari proses pembelajaran. Upaya mengatasi permasalahan tersebut, pendidik berkewajiban untuk mengembangkan model pembelajaran yang dapat mengembangkan keterampilan berpikir dan pemahaman siswa. Terkait dengan itu, maka cara terbaik bagi siswa untuk mempelajari sainsadalah dengan menghadapkan mereka pada masalah otentik yang menantang dan menggugah pikirannya, merangsang kebiasaan berpikir, mengeluarkan gagasan, dan melakukan tindakan yang berhubungan dengan pemecahan masalah yang ada di masyarakat dan lingkungan sekitar siswa.

Pembelajaran fisika sebaiknya menghadirkan permasalahan yang berkaitan dengan konsepkonsep fisika kemudian mengarahkan siswa pada pemecahan masalah tersebut, Sehingga pembelajaran fisika akan lebih menarik bagi siswa. Siswa akan lebih aktif dalam belajar dan mampu mengaitkan konsep-konsep fisika dalam menganalisis permasalahan-permasalahan yang ada. Terlebih jika permasalahan yang diberikan merupakan masalah-masalah yang sering mereka jumpai di lingkungan sekitar.

Kegiatan pemecahan masalah terhadap permasalahan fisika yang ada di lingkungan pada akhirnya siswa akan terbiasa memecahkan masalah fisika yang dihadapi dalam kehidupan sehari-hari, sehingga dapat meningkatkan aktivitas belajar siswa di kelas dan 


\section{Jurnal Pendidikan Fisika Tadulako (JPFT) \\ Vol. 1 No. 2}

ISSN 23383240

meningkatkan hasil belajar siswa. Selain itu, Pendekatan pembalajaran berbasis masalah adalah dapat memberikan penjelasan terhadap pemahaman tentang suatu masalah yang kompleks sebelum mencoba memecahkan masalahnya [1].

Berdasarkan penjelasan di atas, model pembelajaran yang diimplementasikan agar siswa terbiasa dengan masalah fisika yang menyangkut kehidupan sehari-hari yaitu model pembelajaran berbasis masalah. Pembelajaran berbasismasalahmerupakan sebuah pendekata $\mathrm{n}$ pembelajaran yang menyajikan masalah kontekstual sehingga merangsang siswa untuk belaja [2]. Selain itu, model pembelajaran berdasarkan masalah dapat memberikan pengalaman bermakna kepada siswa, karena mereka dapat terlibat langsung dalam pembelajaran lebih aktif dan terbiasa serta terlatih untuk mampu memecahkan atau menyelesaikan masalah-masalah yang diberikan, sehingga dapat meningkatkan kemampuan memecahkan masalah fisika pada siswa [3]. Memecahkan permasalahan fisika, dibutuhkan minat belajar siswa yang tinggi. Minat belajar siswa dapat ditingkatkan maka kemampuan dalam memecahkan permasalahan fisika yang diberikan akan lebih baik, sebab dengan adanya minat belajar, siswa akan cenderung tetap memperhatikan dan mengenang beberapa aktivitas atau kegiatan dalam proses belajar mengajar. Oleh karena itu, guru memiliki peranan penting untuk menciptakan suasana belajar yang menarik yang dapat meningkatkan minat belajar pada siswa. Sehingga melalui pembelajaran berbasis masalah diharapkan dapat meningkatkan hasil belajar siswa.

SMA Negeri 5 Palu merupakan salah satu sekolah unggulan yang ada di kota Palu. Berdasarkan pengamatan di kelas khususnya kelas XI IPA dalam pembelajaran fisika masih menggunakan metode ceramah sehingga menimbulkan kejenuhan dalam proses pembelajaran. Kurang aktifnya siswa dalam proses pembelajaran ini berdampak pada hasil belajar yang kurang maksimal. Siswa yang aktif dalam proses pembelajaran di kelas masih kurang diterapkan. Berdasarkan penjelasan di atas, peneliti bermaksud untuk melakukan penelitian tentang pengaruh model pembelajaran berbasis masalah terhadap hasil belajar fisika pada siswa kelas XI SMA Negeri 5 Palu

\section{METODOLOGI PENELITIAN}

Penelitian ini merupakan penelitian eksperimen kuasi dengan mengambil dua kelas secara purposive pada sekolah SMA Negeri 5 Palu. Kedua kelas ini yaitu kelas XI IPA 1 sebagai kelas eksperimen yang mengikuti model pembelajaran berbasis masalah dan kelas XI IPA 3 sebagai kelas kontrol yang mengikuti model Pembelajaran konvensional. Ruang lingkup dalam penelitian ini hanya mencakup pada hasil belajar kognitif siswa serta materi HukumHukum Newton tentang Gerak dan Gravitasi.

Data yang diambil dari penelitian ini yaitu hasil belajar siswa berupa tes yang diberikan pada awal pertemuan dan akhir pertemuan setelah diberikan perlakuan. Untuk lebih jelasnya desain penelitian yang digunakan dalam penelitian ini adalah sebagai berikut:

\section{Tabel 1. The non ekivalen pretest-postest design rancangan prates-pascates yang} tidak ekuivalen

\begin{tabular}{|c|c|c|c|}
\hline Group & $\begin{array}{c}\text { Tes } \\
\text { Awal }\end{array}$ & Perlakuan & $\begin{array}{c}\text { Tes } \\
\text { Akhir }\end{array}$ \\
\hline $\begin{array}{c}\text { Kelas } \\
\text { eksperimen }\end{array}$ & $\mathrm{O}_{1}$ & $\mathrm{X}_{1}$ & $\mathrm{O}_{1}$ \\
\hline Kelas control & $\mathrm{O}_{1}$ & $\mathrm{X}_{2}$ & $\mathrm{O}_{1}$ \\
\hline
\end{tabular}

Keterangan :

$\mathrm{X}_{1}$ : Model pembelajaran berbasis masalah

$\mathrm{X}_{2}$ : Model pembelajaran konvensional

$\mathrm{O}_{1}$ : Tes awal (preetest) dan Tes akhir (posttest) [4].

\section{HASIL DAN PEMBAHASAN}

Data pretest digunakan untuk mengetahui keadaan awal kelas, dan data posttest digunakan untuk mengetahui ada tidaknya perbedaan hasil belajar siswa setelah diberikan perlakuan yang berbeda, sehingga dari 
ISSN 23383240

perbedaan tersebut dapat dilihat pengaruh dari pembelajaran berbasis masalah terhadap hasil belajar fisika.

Tabel 2. Model Pembelajaran Berbasis Masalah

\begin{tabular}{|c|c|c|}
\hline Nilai & Tes Awal & Tes Akhir \\
\hline Rata-rata Nilai & 8,70 & 20,35 \\
\hline Standar deviasi & 3,06 & 3,16 \\
\hline
\end{tabular}

Tabel 3. Model Pembelajaran Konvensional

\begin{tabular}{|c|c|c|}
\hline Nilai & $\begin{array}{c}\text { Tes } \\
\text { Awal }\end{array}$ & Tes Akhir \\
\hline $\begin{array}{c}\text { Rata-rata } \\
\text { Nilai }\end{array}$ & 9,00 & 16,64 \\
\hline $\begin{array}{c}\text { Standar } \\
\text { deviasi }\end{array}$ & 3,16 & 3,68 \\
\hline
\end{tabular}

Pada pengujian ini menggunakan uji Statistik yaitu uji-t (dua pihak) diperoleh $t$ hitung untuk pretest $=0,35 \mathrm{t}$ tabel $=2,01 \mathrm{H}_{0}$ berdasarkan syarat dan ketentuan $\mathrm{H}_{0}$ diterima jika -tabel< $t_{\text {hitung }}<t_{\text {tabel }}$ harga lain $\mathrm{H}_{0}$ ditolak. Sedangkan $\mathrm{t}$ hitung untuk posttest $=3,98$ berdasarkan syarat dan ketentuan $\mathrm{H}_{0}$ diterima jika $-\mathrm{t}_{\text {tabel }}<\mathrm{t}_{\text {hitung }}<$ tabel harga lain $\mathrm{H}_{0}$ ditolak. tabel pada taraf signifikansi 0,05 dan $\mathrm{dk}=\mathrm{n}_{1}+\mathrm{n}_{2}-2=26+28$ - $2=52$ pada tabel distribusi tabel $=2,01$ dan $t_{\text {hit }}=3,98$, Dapat disimpulkan bahwa $\mathrm{t}$ hitung berada pada di daerah penolakan $H_{0}$, yaitu $t_{\text {tabel }}=2,01<t_{\text {hitung }}=3,98<t_{\text {tabel }}=2,01$ dengan demikian Ho ditolak dan $H_{1}$ diterima.

Sesuai dengan perencanaan penelitian, kegiatan pembelajaran dilakukan sebanyak 6 kali pertemuan, terdiri dari 4 kali tatap muka di kelas dalam proses pembelajaran dan dua kali pertemuan untuk pretest dan postest baik kelas kontrol mau pun kelas eksperimen. Test hasil belajar yang diberikan berjumlah 30 butir soal yang telah diuji validitas. Pada penelitian ini digunakan model pembelajaran yang berbeda. Kelas XI IPA 1 sebagai kelas eksperimen peneliti menerapkan model pembelajaran berbasis masalah, sedangakan pada kelas XI IPA 3 sebagai kelas kontrol menggunakan pembelajaran konvensional.
Pada pertemuan pertama dilakukan pretest sesuai dengan desain penelitian pada kedua kelas. Pretest digunakan untuk mengetahui keadaan awal kedua kelas. Hasil dari pretest menunjukan tidak terdapat perbedaan hasil belajar kedua kelas. Berdasarkan hasil uji-t dua pihak yang dilakukan nilai thitung sebesar 0.35 sedangkan tabel 2.01. Uji-t dua pihak ini menunjukan bahwa $\mathrm{H}_{\circ}$ diterima dan $\mathrm{H}_{1}$ ditolak terlihat - ttabel $=2,01<$ thitung $=0,35<$ tabel $=2,01$, atau tidak terdapat perbedaan hasil belajar kelas XI IPA 1 sebagai kelas eksperimen dan kelas XI IPA 3 yang dijadikan kelas kontrol. Kedua kelas memenuhi syarat dijadikan sampel penelitian karena kedua kelas memiliki keadaan hasil belajar yang sama.

Hasil postest yang telah dilakukan selanjutnya dilakukan uji hipotesis untuk melihat signifikansi perbedaan hasil belajar ke dua kelas. Hasil uji hipotesis yang dilakukan membuktikan terdapat perbedaaan hasil belajar fisika antara kelas kontrol dan kelas eksperimen. Keputusan ini berdasarkan syarat pengambilan keputusan bahwa $\mathrm{H}_{0}$ ditolak dan $\mathrm{H}_{1}$ diterima. Terlihat dari uji $t 2$ pihak menunjukan thitung 3,98 sedangkan tabel 2,01 . Temuan ini menunjukan bahwa $\mathrm{H}_{\mathrm{o}}$ berada pada daerah penolakan terlihat $-t_{\text {tabel }}=2,01<t_{\text {hitung }}=3,98<t_{\text {tabel }}=2,01$, sehingga $\mathrm{H}_{1}$ diteima dan Ho ditolak. Uji $t 2$ pihak menggambarkan signifikansi perbedaan hasil belajar fisika antara siswa yang diajar dengan model pembelajaran berbasis masalah dengan siswa yang diajar dengan model pembelajaran konvensional. Perbedaan yang berarti (signifikan) yang telah ditemukan dari hasil tes akhir kelas eksperimen dan kelas kontrol menunjukan pengaruh dari perlakuan yang diberikan pada kedua kelas tersebut. Perbedaan ini menunjukan bahwa terdapat pengaruh model pembelajaran berbasis masalah terhadap hasil belajar fisika pada siswa kelas XI SMA Negeri 5 Palu.

Temuan lain yang diperolah selama penelitian sampai hasil analisis postest menunjukan bahwa model pembelajaran berbasis masalah mempunyai hasil belajar yang lebih baik dari pada pembelajaran konvensional. Temuan ini diperkuat oleh data yang menunjukan bahwa nilai rata-rata siswa yang 
ISSN 23383240

menggunakan model pembelajaran konvensional adalah 20.35. Sedangkan nilai rata-rata kelas yang menggunakan model pembelajaran konvensional adalah 16.64.

Model pembelajaran berbasis masalah berpengaruh terhadap hasil belajar fisika pada penelitian ini kerena dalam setiap tahap model pembelajaran berbasis masalah menuntut siswa untuk lebih aktif, kritis dan bertanggungjawab dalam proses pembelajaran sehingga dapat melatih siswa dalam menemukan gagasan baru. Semua ini tidak terlepas dari keaktifan siswa dalam proses pembelajaran dan keseriusan dalam setiap langkah pembelajaran. Pembagian kelompok yang heterogen dan setiap kelompok mencari dan memecahkan sendiri masalah yang terterah dalam lembar kerja siswa (LKS) yang merupakan media dari pembelajaran berbasis masalah. Keseriusan siswa dalam proses pemecahan masalah berdampak pada penguasaan konsep tiap indikator pembelajaran sehingga berpengaruh pada hasil belajar siswa.

Tahap pembelajaran berbasis masalah dirancang untuk siswa lebih aktif dalam proses pemebelajaran. Kegiatan inti pembelajaran bagian eksplorasi siswa dihadapkan pada masalah, sehingga siswa secara aktif mengeluarkan pendapat atau jawaban sederhana pada masalah tersebut. Masalah yang diberikan adalah masalah yang autentik, nyata dalam kehidupan sehari-hari. Menghadapkan siswa pada masalah terbukti dapat membuat siswa lebih termotivasi dalam mencari dan menemukan jawaban dari masalah tersebut.

Tahap elaborasi pada fase mengorientasikan siswa untuk belajar dan fase membimbing penyelidikan individu maupun kelompok merupakan tahap melatih siswa untuk mencari masalah sendiri dan memecahkan masalah tersebut sesuai dengan konsep yang dipelajari. Lembar kerja siswa yang dibagikan pada masing-masing kelompok dalam pemebelajaran berbasis masalah merupakan pengganti sebagian peran guru dalam proses pembelajaran. Tahap elaborasi membuat siswa lebih bertanggungjawab terhadap hasil karya atau hasil pemecahan masalah. Siswa mempresentasikan hasil pemecahan masalah yang telah dibuat. Fase mengembangkan dan menyajikan hasil karya kelompok dimamfaatkan siswa untuk tukar informasi kepada kelompok lain sehingga membuat siswa lebih aktif dalam proses pembelajaran.

Tahap konfirmasi pada pembelajaran berbasis masalah terdapat fase terakhir yaitu menganalisis dan mengevaluasi proses pemecahan masalah. Tahap ini merupakan salah satu keunggulan pembelajaran berbasis masalah. Siswa bersama dengan guru membandingkan hasil pemecahan masalah yang telah dilakukan oleh siswa dengan pemecahan masalah yang dilakukan oleh para ahli atau dengan konsep yang sebenarnya.

Keunggulan-keunggulan tahap pembelajaran ini yang membuat adanya pemngaruh positif model pembelajran berbasis masalah dibandingkan model pembelajran konvensional pada penelitian yang telah dilakukan. Lestari menyatakan berdasarkan temuan model pembelajaran berbasis masalah merupakan salah satu model pembelajaran yang memberikan pengaruh positif terhadap peningkatan prestasi belajar fisika terutama bagi siswa yang memiliki motivasi belajar tinggi [5]. Menurut Sukandi, Pendekatan konvensional ditandai dengan guru lebih banyak mengajarkan tentang konsep-konsep bukan konpetensi, tujuannya adalah siswa mengetahui sesuai bukan untuk melakukan sesuatu, dan pada saat proses pembelajaran siswa lebih banyak mendengarkan [6].

\section{KESIMPULAN}

Berdasarkan hasil perhitungan statistik didapatkan harga thitung sebesar 3,98 dan ttabel pada taraf signifikansi $0,05 \mathrm{dan} \mathrm{dk}=52$ adalah 2,01 , hasil ini berada pada daerah penolakan Ho yakni $-t_{\text {tabel }}=2,01<$ thitung $=3,98<t_{\text {tabel }}=$ 2,01 . Penelitian ini menunjukkan bahwa hipotesis $(\mathrm{Ho})$ ditolak dan hipotesis penelitian $\left(\mathrm{H}_{1}\right)$ diterima atau terdapat perbedaan hasil belajar fisika antara kelas eksperimen dan kelas kontrol. Berdasarkan hasil uji hipotesis tersebut penelitian ini dapat disimpulkan bahwa terdapat pengaruh model pembelajaran berbasis masalah terhadap hasil belajar fisika pada siswa kelas XI SMA Negeri 5 Palu. 


\section{DAFTAR PUSTAKA}

[1] Barbara, L. (2012). Problem-based Learning applied to Team Environments: A Visual Literature Review. Information Technology Education. Capella University USA

[2] Major, dkk. (2001). Assessing the Effectiveness of Problem-

Based Learning in Higher Education: Lessons from the Literature. [Online]. Tersedia : www.rapidintellect.co m/AE Qweb/mop4spr01.htm [Oktober 2012]

[3] Dawean, D. (2011). Penerapan model pembelajaran berdasarkan masalah (problem based learning) untuk meningkatkan kemampuan memecahkan masalah fisika pada siswa kelas XI IPA 2 SMA Negeri 1 Marawola. Jurnal: Tidak dipublikasikan

[4] Sugiyono. (2008). Metode Penelitian Kuantitatif Kualitatif dan $R \& D$. Bandung: Alfabeta.

[5] Lestari ,S . ( 2010). Pengaruh Model Pembelajaran Berbasis Masalah (Problem Based Learning) dan Motivasi Belajar Terhadap Prestasi Belajar Fisika Bagi Siswa Kelas VII SMP Jurnal: diterbitkan

[6] Sukandi. (2003), Model Pembelajaran Konvensional .tersedia:http://belajar nonstop.blogspot.com/2013/03/metode-pembelajarankonvensional.html [Desember 2012] 